\title{
A new evolutionary unit in the Excirolana braziliensis species complex
}

\author{
Julia Losada Tourinho*, Alejandro Márquez, Eleonora Celentano, Omar Defeo
}

\author{
UNDECIMAR, Facultad de Ciencias, Universidad de la República \\ (Iguá 4225, PO Box 10773, Montevideo 11400, Uruguay) \\ *Corresponding author: julia.tourinho@gmail.com \\ Financial Support: ANII - Agencia Nacional de Investigación e Innovación, post-doctoral scholarship PD_NAC_2013_10421.
}

Cryptic species are biological entities that are difficult to recognize on the basis of morphology (BICKFORD et al., 2007; KNOWLTON, 1993). Several cases of cryptic species have been reported for marine species with relatively wide geographical range and low dispersal potential (BAIRD et al., 2011; BOISSIN et al., 2008; CARR et al., 2011; HELD; WÄGELE, 2005; LARSEN et al., 2014; MARKOW; PFEILER, 2010; RAUPACH et al., 2007; REMERIE et al., 2006; SPONER; LESSIOS, 2009; VARELA; HAYE, 2012; XAVIER et al., 2016). In a low dispersal scenario, as in many marine brooders, isolation by distance and outbreeding depression are enough to account for a high speciation rate (HOELZER et al., 2008).

Cirolanid isopods inhabit the supralittoral and intertidal fringes of sandy beaches around the world, being dominant in terms of number and, in some cases, biomass (DEFEO et al., 1992; VELOSO; CARDOSO, 2001). Excirolana braziliensis Richardson, 1912 constitutes one of the most ubiquitous species on sandy beaches of the Americas (DEXTER, 1977). It has a wide Pan-American distribution, from $31^{\circ} \mathrm{N}$ (DEXTER, 1976) to ca. $42^{\circ} \mathrm{S}$ (JARAMILLO et al., 2000), occurring on tropical, subtropical and temperate sandy beaches along the Atlantic and Pacific coasts of the Americas (DEFEO et al., 1997). The species is ovoviviparous and has no larval dispersal, with low genetic exchange among populations (KLAPOW, 1970), favoring an exceptional degree of genetic differentiation between populations (WEINBERG; STARCZAK, 1989).

Cryptic species among individuals identified as Excirolana braziliensis have been detected on beaches of Panama (SPONER; LESSIOS, 2009) and Chile (VARELA; HAYE, 2012) using analyses of partial sequences of the Cytochrome Oxidase subunit 1 gene. In this paper, we present genetic evidence that shows that Uruguayan populations of Excirolana braziliensis represent a hitherto undescribed significant evolutionary unit. We also discuss its relationship with the Chilean and Panamanian evolutionary units.

Individuals of Excirolana braziliensis were collected from eight localities along the coast of Uruguay, including estuarine and oceanic beaches, which span the entire species distribution range in the country (Figure 1). Each sampling site was visited only once between February and September 2014. All individuals were identified in the laboratory with the use of an optical microscope and stored in ethanol $95 \%$ at $-20^{\circ} \mathrm{C}$. Tissue DNA was extracted using a modified CTAB protocol (CTAB $2 \%$, EDTA $20 \mathrm{mM}$, NaOAc $3 \mathrm{M}$, Tris $100 \mathrm{mM}$ ). Only the telson muscle of each individual was used, unless individuals were smaller than $5 \mathrm{~mm}$, in which case the whole body was used. The COI marker was selected since it was the gene used by VARELA and HAYE (2012) and SPONER and LESSIOS (2009) in their studies of E. braziliensis genetic diversity, and it has been successfully used for the detection of cryptic species in marine invertebrates (COSTA et al., 2007).

A partial sequence of the Cytochrome Oxidase subunit I gene (COI) was amplified using universal primers HCO2198 and LCO1490 (FOLMER et al., 1994). PCR reactions contained 1x reaction buffer, $2.5 \mathrm{mM}$ of $\mathrm{MgCl}$, $0.3 \mathrm{mM}$ of each primer, $0.2 \mathrm{mM}$ of dNTP mixture, 1 unit of Taq DNA polymerase (Thermo Scientific) and $1 \mathrm{~mL}$ of DNA template ( $20 \mathrm{ng}$ ), in a final volume of $25 \mathrm{~mL}$. Cycling conditions were as follows: initial denaturation at $93^{\circ} \mathrm{C}$ for 3 min followed by 35 cycles of 1 min denaturation at $93^{\circ} \mathrm{C}, 1 \mathrm{~min}$ annealing at $48^{\circ} \mathrm{C}$ and 1 min extension at $72{ }^{\circ} \mathrm{C}$, ending with a final extension at $72{ }^{\circ} \mathrm{C}$ for $3 \mathrm{~min}$. Purification of PCR products and sequencing were done by Macrogen company (www.macrogen.com).

Sequences obtained by Macrogen were edited using SeqMan Pro ${ }^{\mathrm{TM}}$ (DNASTAR, Inc.) and aligned with Muscle 


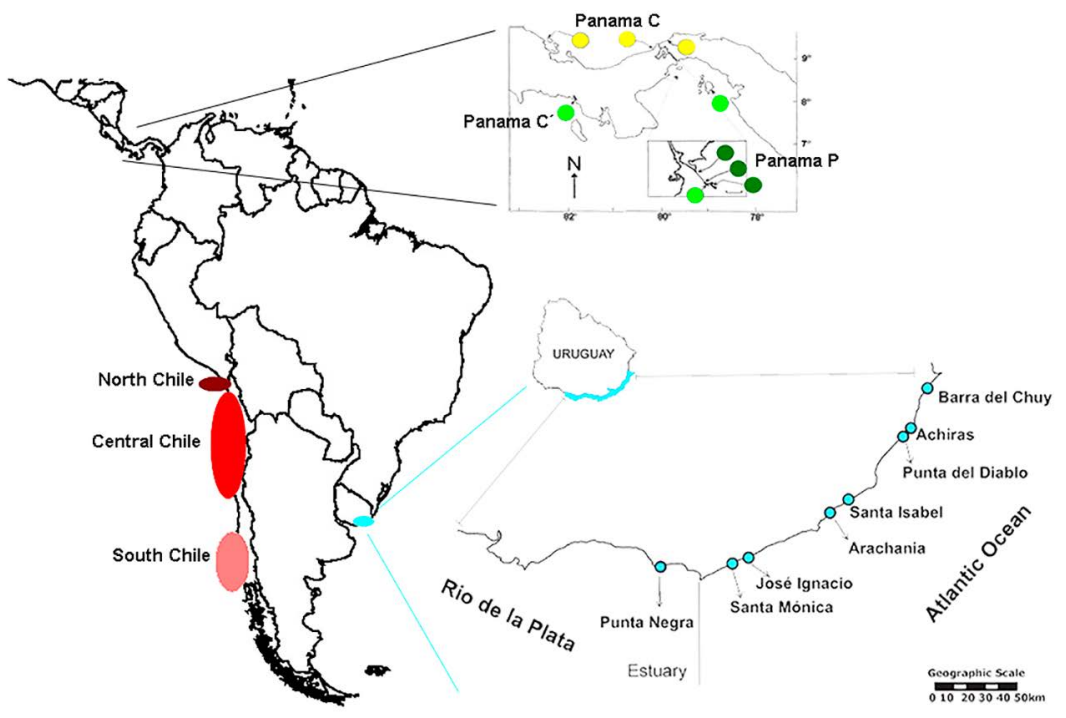

Figure 1. Map with locations of origin of sequences of Excirolana braziliensis used in this study. Panama map was modified from SPONER and LESSIOS 2009.

algorithm in MEGA version 6 (TAMURA et al., 2013) (GenBank Accession numbers: KT870118 to KT870130). This alignment was used to obtain diversity indices in DnaSP v5 (LIBRADO; ROZAS, 2009). The sequences obtained were compared to previously published COI sequences of $E$. braziliensis from Chile (VARELA; HAYE, 2012) and from Panama (SPONER; LESSIOS, 2009), available in the GenBank database. Since the sequences differed in size, we chose to create an alignment including missing information in order to use the largest amount of information possible in each analysis.

The model that best described the genetic variation found between sequences was kimura-2-parameter plus gamma $(\mathrm{K} 2 \mathrm{P}+\mathrm{G})$, determined by Mega using lowest BIC (Bayesian Information Criteria) scores. In order to understand the relationship between groups of samples from different locations, a Neighbor-joining (NJ) tree was built using pairwise deletion option in MEGA, using two sequences of Excirolana hirsuticauda as an outgroup (GenBank accession numbers: FJ532223 and FJ532224). Genealogical relationships between haplotypes were recovered through a parsimony haplotype network built using Median-joining option in NETWORK v.4.6.1.3 (http://www.fluxus-engineering.com). Pairwise distances were obtained using Kimura-2-parameter model (K2P) in MEGA. The genetic structure between Uruguayan beaches was assessed by an analysis of molecular variance (AMOVA) and $F_{\text {ST }}$ values were estimated in Arlequin v.3.5 (EXCOFFIER; LISCHER, 2010).
We obtained 142 sequences of 473 base pairs (bp) of Excirolana braziliensis. Overall, the sequences showed low polymorphism in only 12 haplotypes (Haplotype diversity $=0.237$; nucleotide diversity $=0.006$ ). The $\mathrm{NJ}$ tree showed Uruguay as a single clade, while preserving the six already described clades of Panama and Chile (Figure 2). Only Uruguay presented a monophyletic group with good support and was recovered as an outgroup of the Panamanian and Chilean groups. The relationship between the Panamanian and Chilean clades may evidence a complex evolutionary history of E. braziliensis on the Pacific coast, but the exact relationship between them could not be recovered due to low bootstrap values.

The haplotype network indicated an absence of structure for Uruguayan beaches, with no evidence of regional clusters of haplotypes (Figure 3). No haplotypes were shared between countries. Haplotypes from Uruguay were more closely related to the South Chile group, but were separated by several mutation steps, differences equivalent to those found between each haplotype group. The relationship between the Panamanian and Chilean samples in the parsimony network produced a result similar to the $\mathrm{NJ}$ tree (Figures 2 and 3).

Genetic distance values (K2P) between the Uruguayan samples were very low, with no differences between oceanic and estuarine beaches $(0-0.006)$. Population analyses of Uruguayan samples were concordant, failing to detect any common population structure between estuarine and oceanic beaches (AMOVA, $F_{\text {CT }}=-0.007, p=0.45 ; F_{S T}<0,034$, > $0.14)$. The Uruguayan samples showed a similar genetic 


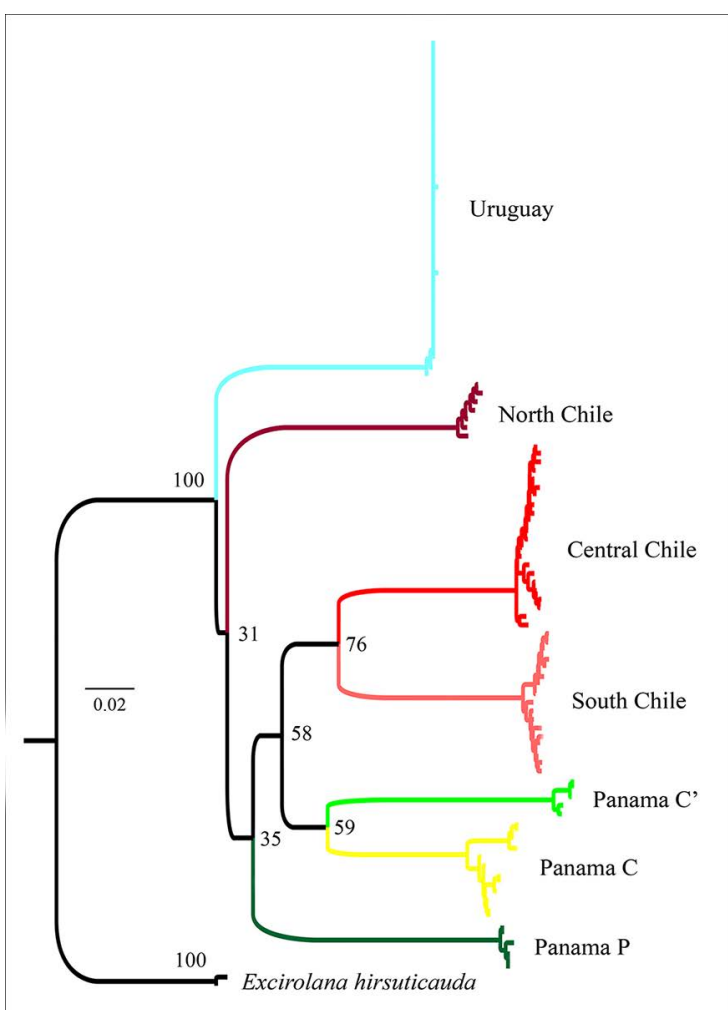

Figure 2. Neighbor-joining tree reflecting the relationship between sequences of Excirolana braziliensis from Uruguay, Chile and Panama. Sequences of E. hirsuticauda were used as outgroup. Numbers on nodes indicate bootstrap values (1000 replicates).

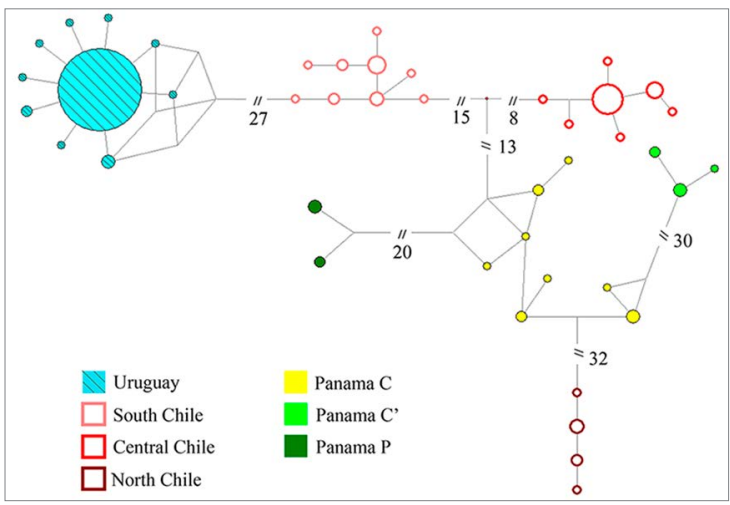

Figure 3. Excirolana braziliensis. Median-joining haplotype network constructed using sequences from Uruguay, Chile and Panama. Each circle represents a distinct haplotype. Sizes of haplotypes are proportional to their frequency. Distance between haplotypes reflects the amount of mutational steps. // indicates that the line was shortened and the number shown next to this symbol indicates the number of mutation steps between haplotypes.

distance when compared to the Chilean and Panamanian samples $(0.191-0.233$ and $0.193-0.246$, respectively). The genetic distances found between individuals from the different monophyletic groups were approximately ten times higher than intra-group distance values $(0-0.029$ and $0.154-0.261$ ).

Excirolana braziliensis from Uruguayan beaches constitute a homogenous and monophyletic group, well differentiated from individuals found on the West Pacific coast. The absence of published data of different molecular markers prevented further evaluation of genetic differences between samples from Chile and Panama. However, the high levels of divergence found between the distinct monophyletic groups described in this study are very similar to levels found between congeneric species of crustaceans (COSTA et al., 2007). This result, together with the known life history traits of these taxa, is enough to leave no doubt that individuals of E. braziliensis from Uruguay are evolving as an evolutionary unit distinct from those present in Chile and in Panama. A wider sampling area, including sites from Argentina and Brazil, is necessary to determine the distribution limits of this lineage.

Differing from the findings of VARELA and HAYE (2012) and SPOONER and LESSIOS (2009), the population of $E$. braziliensis from Uruguay showed very small diversity and no signs of geographical structure along approximately $240 \mathrm{~km}$ of coast. There were no differences between individuals inhabiting estuarine and oceanic beaches of the Uruguayan coast. Although the genetic distance values obtained between individuals from Uruguayan beaches were very low, the geographical distances covered by the samples were greater than the ones from Panama, indicating that geographical distance is not the factor from which differentiation in E. braziliensis is derived.

Results suggest that individuals from Uruguay are more closely related to individuals from South Chile than to those from Panama, which might suggest a southern route of expansion for this species. In addition, the closer relationship between samples from Panama and North Chile may indicate that the Chilean populations may have different evolutionary origins. However, more evidence is needed to verify these hypotheses, including more genetic markers, longer sequences and samples from other beaches on the Atlantic and Pacific coasts.

The genetic differentiation found between latitudes agrees with biological differences assigned to phenotypic plasticity by CARDOSO and DEFEO (2004), indicating they may have evaluated different evolutionary units as one. In a biogeographical context, CARDOSO and DEFEO 
(2003) reported that breeding and recruitment shift from continuous to seasonal from tropical to temperate beaches, suggesting environmental changes might have played a role as a selective force for this species. It is important to analyze samples from northern populations of the Atlantic to get a better picture of the evolutionary history of this group.

All evidences described in this paper indicate that Uruguayan populations of Excirolana braziliensis belong to a distinct evolutionary unit, reinforcing the hypothesis that the binomial E. braziliensis represents a complex of species.

\section{ACKNOWLEDGEMENTS}

This study is part of the Post-Doctoral project of J. L. Tourinho, financed by ANII (PD_NAC_2013_10421). We wish to thank Alfredo Pereira for allowing us to use the facilities of the Laboratorio de Genética at DINARA. We also acknowledge DINARA and CSIC Grupos for their financial suppport.

\section{REFERENCES}

BAIRD, H. P.; MILLER, K. J.; STARK, J. S. Evidence of hidden biodiversity, ongoing speciation and diverse patterns of genetic structure in giant Antarctic amphipods. Mol. Ecol., v. 20, n. 16, p. 3439-3454, 2011.

BICKFORD, D.; LOHMAN, D. J.; SODHI, N. S.; NG, P. K. L.; MEIER, R.; WINKER, K.; INGRAM, K. K.; DAS, I. Cryptic species as a window on diversity and conservation. Trends Ecol. Evol., v. 22, n. 3, p. 148-155, 2007.

BOISSIN, E.; FÉRAL, J. P.; CHENUIL, A. Defining reproductively isolated units in a cryptic and syntopic species complex using mitochondrial and nuclear markers: the brooding brittle star, Amphipholis squamata (Ophiuroidea). Mol. Ecol., v. 17, n. 7, p. 1732-1744, 2008.

CARDOSO, R. S.; DEFEO, O. Geographical patterns in reproductive biology of the Pan-American sandy beach isopod Excirolana braziliensis. Mar. Biol., v. 143, n. 3, p. 573-581, 2003.

CARDOSO, R. S.; DEFEO, O. Biogeographic patterns in life history traits of the Pan-American sandy beach isopod Excirolana braziliensis. Estuar. Coast. Shelf Sci., v. 61, n. 3, p. 559-568, 2004.

CARR, C. M.; HARDY, S. M.; BROWN, T. M.; MACDONALD, T. A.; HEBERT, P. D. N. A Tri-oceanic perspective: DNA barcoding reveals geographic structure and cryptic diversity in Canadian polychaetes. PLoS ONE, v. 6, n. 7, p. e22232, 2011.

COSTA, F. O.; DEWAARD, J. R.; BOUTILLIER, J.; RATNASINGHAM, S.; DOOH, R. T.; HAJIBABAEI, M.; HEBERT, P. D. N. Biological identifications through DNA barcodes: the case of the Crustacea. Can. J. Fish. Aquat. Sci., v. 64, n. 2 , p. $272-295,2007$.
DEFEO, O.; BRAZEIRO, A.; DE ALAVA, A.; RIESTRA, G. Is sandy beach macrofauna only physically controlled? Role of substrate and competition in Isopods. Estuar. Coast. Shelf Sci., v. 45, n. 4, p. 453-462, 1997.

DEFEO, O.; JARAMILlO, E.; LYONNET, A. Community structure and intertidal zonation of the macroinfauna on the Atlantic coast of Uruguay. J. Coast. Res., v. 8, n. 4, p. 830-839, 1992.

DEXTER, D. M. The sandy-beach fauna of Mexico. Southwest. Nat., v. 20, n. 4, p. 479, 1976.

DEXTER, D. M. Natural history of the Pan-American sand beach isopod Excirolana braziliensis (Crustacea: Malacostraca). J. Zool., v. 183, n. 1, p. 103-109, 1977.

EXCOFFIER, L.; LISCHER, H. E. L. Arlequin suite ver 3.5: A new series of programs to perform population genetics analyses under Linux and Windows. Mol. Ecol. Resour., v. 10, n. 3, p. 564-567, 2010.

FOLMER, O.; BLACK, M.; HOEH, W.; LUTZ, R.; VRIJENHOEK, R. DNA primers for amplification of mitochondrial cytochrome $\mathrm{c}$ oxidase subunit I from diverse metazoan invertebrates. Mol. Mar. Biol. Biotechnol., v. 3, n. 5, p. 294-299, 1994.

HELD, C.; WÄGELE, J. W. Especiación críptica en el isópodo gigante antártico Glyptonotus antarcticus (Isopoda, Valvifera, Chaetiliidae). Sci. Mar., v. 69, Suppl. 2, p. 175-181, 2005.

HOELZER, G. A.; DREWES, R.; MEIER, J.; DOURSAT, R. Isolation-by-distance and outbreeding depression are sufficient to drive parapatric speciation in the absence of environmental influences. PLoS Comput. Biol., v. 4, n. 7, p. e1000126, 2008.

JARAMILlO, E.; DUARTE, C.; CONTRERAS, H. Sandy beach macroinfauna from the coast of Ancud, Isla de Chiloé, southern Chile. Rev. Chil. Hist. Nat., v. 73, n. 4, p. 771-786, 2000 .

KLAPOW, L. A. Ovoviviparity in the genus Excirolana (Crustacea: Isopoda). J. Zool., v. 162, n. 3, p. 359-369, 1970.

KNOWLTON, N. Sibling species in the sea. Annu. Rev. Ecol. Syst., v. 24, p. 189-216, 1993.

LARSEN, K.; TUYA, F.; FROUFE, E. Genetic divergence of tanaidaceans (Crustacea: Peracarida) with low dispersal ability. Sci. Mar. v. 78, n. 1, p. 81-90, 2014.

LIBRADO, P.; ROZAS, J. DnaSPv5: a software for comprehensive analysis of DNA polymorphism data. Bioinformatics, v. 25, n. 11, p. 1451-1452, 2009.

MARKOW, T. A.; PFEILER, E. Mitochondrial DNA evidence for deep genetic divergences in allopatric populations of the rocky intertidal isopod Ligia occidentalis from the eastern Pacific. Mol. Phylogenet. Evol., v. 56, n. 1, p. 468-473, 2010.

RAUPACH, M. J.; MALYUTINA, M.; BRANDT, A.; WÄGELE, J. W. Molecular data reveal a highly diverse species flock within the munnopsoid deep-sea isopod Betamorpha fusiformis (Barnard, 1920) (Crustacea: Isopoda: Asellota) in the Southern Ocean. Deep Sea Res. Part II Top. Stud. Oceanogr., v. 54, n. 16-17, p. 1820-1830, 2007.

REMERIE, T.; BOURGOIS, T.; PEELAERS, D.; VIERSTRAETE, A.; VANFLETEREN, J.; VANREUSEL, A. Phylogeographic patterns of the mysid Mesopodopsis slabberi (Crustacea, Mysida) in Western Europe: evidence for high molecular diversity and cryptic speciation. Mar. Biol., v. 149, n. 3, p. 465-481, 2006.

RICHARDSON, H. Descriptions of a new genus of isopod 
crustaceans, and of two new species from South America. Proc. United States Natl. Museum, v. 43, p. 201-204, 1912.

SPONER, R.; LESSIOS, H. A. Mitochondrial phylogeography of the intertidal isopod Excirolana braziliensis on the two sides of the Isthmus of Panama. Proc. Smithson. Contrib. Mar. Sci. Symp., v. 38, n. 1, p. 219-228, 2009.

TAMURA, K.; STECHER, G.; PETERSON, D.; FILIPSKI, A.; KUMAR, S. MEGA6: Molecular Evolutionary Genetics Analysis version 6.0. Mol. Biol. Evol., v. 30, n. 12, p. 27252729, 2013.

VARELA, A. I.; HAYE, P. A. The marine brooder Excirolana braziliensis (Crustacea: Isopoda) is also a complex of cryptic species on the coast of Chile. Rev. Chil. Hist. Nat., v. 85, n. 4, p. 495-502, 2012.
VELOSO, V. G.; CARDOSO, R. S. Effect of morphodynamics on the spatial and temporal variation of macrofauna on three sandy beaches, Rio de Janeiro State, Brazil. J. Mar. Biol. Assoc. U. K., v. 81, n. 03, p. 369-375, 2001.

WEINBERG, J. R.; STARCZAK, V. R. Morphological divergence of Eastern Pacific and Caribbean isopods: effects of a land barrier and the Panama Canal. Mar. Biol., v. 103, n. 2, p. 143-152, 1989

XAVIER, R.; BRANCO, M.; DOS SANTOS, A. M. Using a phylogeographic approach to investigate the diversity and determine the distributional range of an isopod (Crustacea: Peracarida), Stenosoma nadejda (Rezig, 1989) in the Atlantic-Mediterranean region. Hydrobiologia, v. 768, n. 1, p. 315-328, 2016. 